\title{
Historical seismic catalogue updates and site effects considerations for southern Piedmont (Northwest Italy)
}

\author{
Mauro Bonasera (1), Matteo Redana (2) \& Giandomenico Fubelli (1)
}

(1) Department of Earth Sciences, University of Turin, Via Valperga Caluso 35, 10125 Turin

(2) School of Biological Science, University of Aberdeen, Zoology Building Tillydrone Avenue, AB24 2TZ Aberdeen.

Corresponding author e-mail: mauro.bonasera@unito.it

Document type: Short note.

Manuscript received 16 April 2021; accepted 03 September 2021; editorial responsibility and handling by F. Troiani.

\section{ABSTRACT}

In Northwest Italy, the definition of the seismic districts is a debated topic, with relatively scarce literature to pursue the goal of assessing the relative seismic potential. In particular, the southern Piedmont, despite being part of the lowest categories in the Italian seismic zonation map, has been affected by four relevant earthquakes between 5.5 and $6.5 \mathrm{M}$ in the last six centuries.

Starting from the Italian Historical Macroseismic Archive catalogue, a consultation of ten historical archives (in parishes, municipalities, and administrations of Alessandria, Asti, Cuneo, and Turin Provinces) improved the historical seismicity information reported in the Italian Macroseismic Database, verifying the presence of unknown Macroseismic Data Point (MDPs). An analysis of the density of instrumental seismicity epicentres of the last 35 years provides consistency with MDPs density, qualitatively finding spatial correlation between them. In addition, a deepening of earthquakeinduced landslide issue has been performed in a georeferenced environment with the purpose to assess eventual local amplification effects through a geostatistical analysis.

KEY WORDS: seismic hazards, seismic catalogues, historical seismicity, earthquake-induced landslides, geostatistics.

\section{INTRODUCTION}

The present tectonic framework of southern Piedmont is complex: the juxtaposition on a crustal scale between Alps and Apennines led to the development of subsiding depocenter zones, with a lowering of the tectonic activity since the Oligocene. The available seismic lines highlight a contemporary, progressive activation of north-verging thrusts from the west to the east (Mosca et al., 2009), despite the regional seismic potential is commonly associated with two main districts with diverse kinematic features: the Northern Cottian Alps and the Borbera-Grue (NorthWestern Apennines) seismic zones (Forno et al., 2018). For the two major earthquakes recorded in these districts, the 1808 Pinerolo $\left(M_{w}\right.$ 5.64) (Fioraso, 2016) and the 1828 Tortona $\left(M_{w} 5.72\right)$, there is a lack of information concerning the responsible seismogenic sources (Fig. 1). On the contrary, the Italian Database of Individual Seismogenic Sources (DISS Working Group, 2018) identifies as major active fault zones (i) the Saluzzo-Sommariva faulted anticline (Irace et al., 2010) ("SDB" in Fig. 2) and (ii) the Padane Thrust Front ("PTF" in Fig. 2). Furthermore, events of greater magnitude occurred relatively close to the Piedmont border. The 1564 Lantosque $\left(M_{w}\right.$ 5.8) and the 1887 Diano Marina $\left(M_{w} 6.3\right)$ are the two most powerful historically known (Fig. 1), whose detected Macroseismic Data Points (MDPs), the control ground points, are spread over the region.

In this context, the purpose of the research is to find consistency in southern Piedmont seismic behaviour. Particular attention is paid to the western Po Plain, poorly studied in literature from the seismic point of view. Specifically, the aim is to implement the known historical events (i.e., MDPs) by visiting historical archives; then, qualitatively compare the historical seismicity of the area with the instrumental data since 1985. The update of historical seismic data is useful to understand where future earthquakes may occur or at least where damages may be potentially serious. The distribution of eventual new MDPs can also suggest the location where site effects could make an area more vulnerable in case of an earthquake, even if distant. In addition, the relation between landslide activations and earthquakes can help localize these effects (Wasowski et al., 2011). The characterization of the seismic behaviour may provide significant information about seismogenic zone features.

\section{MATERIALS AND METHODS}

\section{HISTORICAL AND INSTRUMENTAL SEISMIC DATA COMPARISON}

An arbitrary study area has been defined for the comparison between historical and instrumental seismic data, including Provinces of Alessandria, Asti, Cuneo, Turin (Fig. 1). All the seismic events parametrized after 1985 with epicentres within the study area were exported from the Italian National Institute of Geophysics and Volcanology (INGV) online catalogue (ISIDE Working Group, 2017), without magnitude threshold (Fig. 2). The known historical seismic events (i.e., all events preceding 1985) were selected from the Italian Historical Macroseismic Archive - ASMI (Rovida et al.,2017), using a polygonal selection around the area of interest; all the events have been considered, 


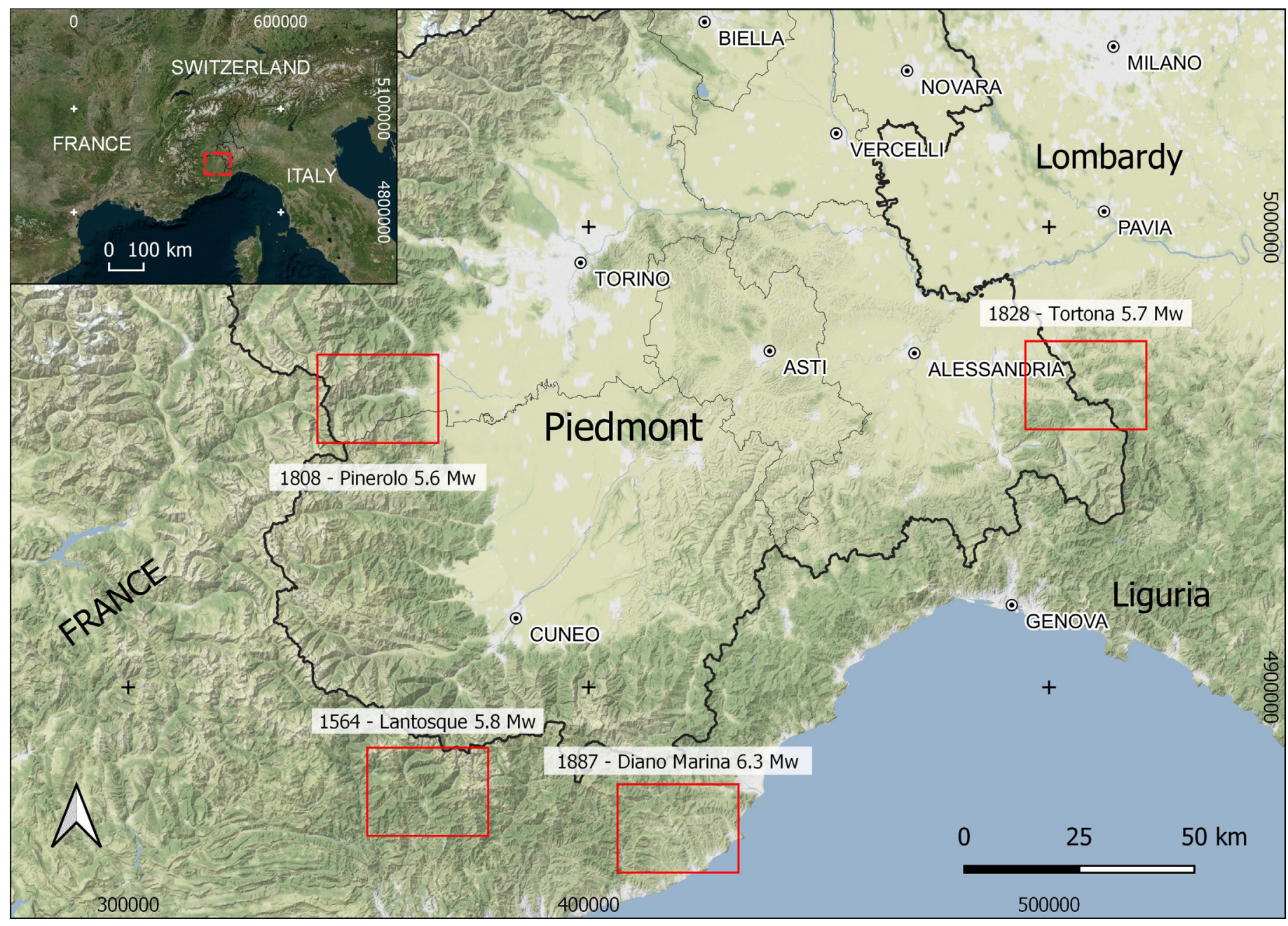

Fig. 1 - Geographic location of the historically strongest earthquakes felt in Piedmont (coordinates in WGS84 UTM 32N) flanked by inset map with analysis area (red square).

regardless their estimated intensity (Guidoboni \& Ebel, 2009). Only the historical events classified as "Fake" events in the ASMI (i.e., seismic events which previous studies demonstrate the inconsistency of their historical sources) were excluded. Further, 11 historical archives were visited to find unknown evidence of historical seismicity, both for new events or for new Macroseismic Data Point (MDPs) to be attributed to known events (Guidoboni \& Ebel, 2009). In particular archives of the city of Archiepiscopal Archive of Turin, the Historical Archive "Filippo Girardi" of Chieri (TO), the Historical Archive and the Diocesan Historical Archive of Fossano (CN), the Diocesan Historical Archive and the City Library Archive of Alba (CN), the Diocesan Historical Archive of Asti, the Historical Archive of the Museum of Natural History "P. Craveri" of Bra (CN), the Historical Archive of the Italian Meteorological Society of Moncalieri (TO) and the City Library Historical Archive of Carmagnola (TO) have been visited (Fig. 2).

In each archive the available documentation has been reviewed with particular attention to chronicles, diaries, building restoration projects and expenses reports. For each evidence, date and hour of the event, locality, and an evaluation of intensity (I) were recorded as reported in the document, using the Modified Mercalli intensity scale (MCS), or based on the codification used in the Italian Macroseismic Database - DBMI15 (Locati et al., 2021) using the following approach. When the historical documents report detailed description of the physic effects of a seismic event, the MSC intensity has been estimated. When insufficient elements were available to attribute a MCS value (i.e., the description of the effect report generic damages or only state that the events were felt), a letteral codification have been attributed as in DBMI15. Therein a letter qualitatively classifies the seismic intensity, going from Slightly Felt - SF, to Heavy Damage - HD (see Locati et al. 2021 for details). All evidence of seismic events were then compared to the ASMI catalogue and classified as: MDPs already present in the ASMI; new MDPs related to seismic events already known in the ASMI (new MDPs); MDPs related to unknown events (new Events).

The density of epicentres within the study area was determined using the earthquakes occurring since 1985 plus the ASMI historical events with more than 1 MDPs (thus with estimated epicentre) over a 10×10 km grid; the mean magnitude for each cell has been computed. The same procedure has been followed to compute the density of the historical MDPs using ASMI seismic events with one MDP plus the new MDPs found in the archives research. All 


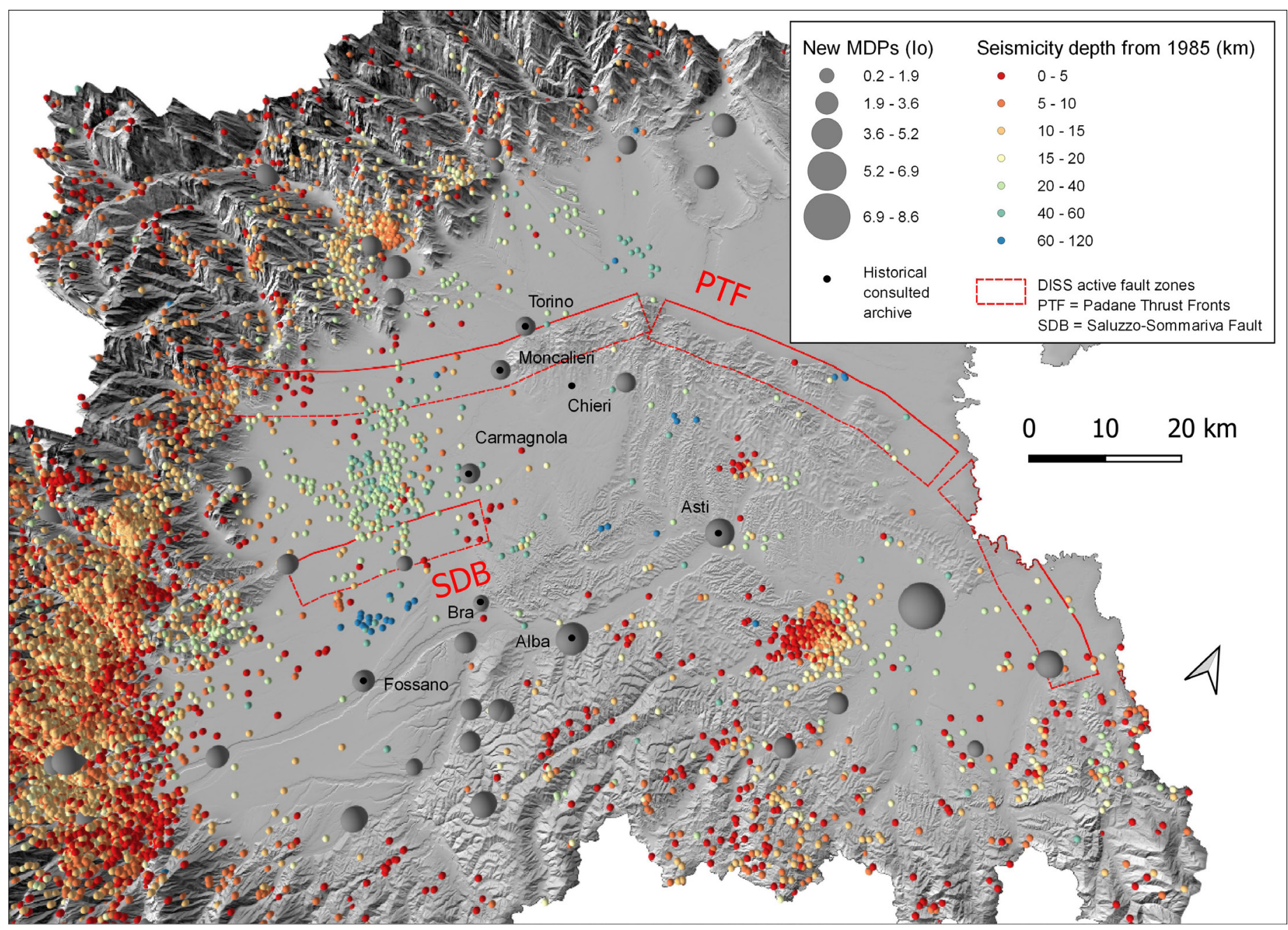

Fig. 2 - Comparison 3D map of instrumental and new historical seismicity. The depth of western epicentres in cold colours is greater than the warmer tones. With grey circles the new MDPs of past earthquakes are shown, and with red lines, the DISS active fault zones are drawn.

MDPs classified as "Fake" in the ASMI, or without enough information to determine its coordinates, were removed from the analysis. The study area herein defined is then qualitatively compared with the current seismic zonation map for the area to find anomalies between the expected seismic behaviour and potential site effects captured by new MDPS.

\section{LANDSLIDE-EARTHQUAKE CORRELATION}

Although recent studies found more accurate the examination of landslide-affected areas by Peak Ground Acceleration (PGA) and topography (Tanyas \& Lombardo, 2019), an attempt to investigate earthquake-landslide relationship with older, but still-effective, magnitudedistance-landslide typologies correlations (Keefer, 1984; Rodriguez et al., 1999) has been performed due to lowintensity earthquake magnitudes registered in Northwest Italy.

Keefer (1984) indicates the relationship between landslide typologies, magnitude, and the area affected by landslides, stating $M_{w}>4.0$ as the threshold under which earthquakes hardly induce any kind of landslide. The 1985-2017 earthquake dataset "Seismicity in Piedmont
- Instrumental seismicity and recent seismicity" (ARPA Piemonte, 2011) and INGV online catalogue (ISIDE Working Group, 2017) have been checked. The landslide dataset "SIFraP - Informative System of Landslides in Piedmont" (ARPA Piemonte, 2004) was examined. Using QGIS 3.10.3 A Coruña, a circular buffer zone was drawn with a different radius, as Keefer (1984) indicated, around the extracted earthquakes to verify an eventual correspondence with the landslide database.

\section{RESULTS}

\section{HISTORICAL DATABASE UPDATES}

The ASMI catalogue reports 20 known historical events within the area. One classified as "Fake" event, eleven nonparametrizable MDPs, and eight classified as MDPs of small events with an estimated magnitude ranging from $4.5 \pm 0.26$ to $3.7 \pm 0.46$ and MCS $>5$, thus included in the Italian Parametric Earthquake Catalogue - CPTI15 (Rovida et al., 2020, 2021).

No new evidence of past seismic events was found in the documentation of the Archiepiscopal Archive of Turin, 
the Historical Archive "Filippo Girardi" of Chieri, the Historical Archive and the Diocesan Historical Archive of Fossano and the Diocesan Historical Archive of Alba.

In total 305 evidence of MDPs, not reported in the ASMI catalogue, were found in the other consulted archives (Tab. 1). Of these, 299 MDPs refers to seismic events, generally with low intensity, not known in the ASMI catalogue, and six are new MDPs of already known events. From the Italian Meteorological Society Archive all the new MDPs, referred to known events outside the study area, were excluded. Within the 305 new MDPs, three groups of MDPs are particularly significative. The first is a group of 84 low intensity MDPs (NF, SF, F - Locati et al. 2021) recorded in Moncalieri between 1867 and 1895; the installation of a seismometer in Moncalieri during the period must be pointed out. The second group of MDPs belongs to a seismic sequence reported in the Supplementary publication of the Periodic "Alba Pompeia" published in 1901 and available in the City Library Archive of Alba. Herein, a sequence of nine major seismic events felt in Alba and surrounding area is reported in January/February 1771 (Tab. 2). The effects of the earthquakes are described, giving the possibility to estimate the intensity of the events, ranging from $\mathrm{F}$ to $\mathrm{HF}$. For one such event, the described effects (little damages to structures, falling objects) allows to assume an MSC intensity of $6(28 / 02 / 1771,21: 45$; Tab. 2$)$. The third group of MDPs belongs to low intensity earthquakes felt in four distinct localities on the $01 \backslash 06 \backslash 1878$ in the Piedmont Apennines area (Tab. 3). The events were reported to the Italian Meteorological Society Bulletin of Moncalieri by the correspondents present during the event.

The MDPs density (single MDPs from ASMI plus new MDPs found by this research) (Fig. 3a) and the seismic events density with known epicentre (post-1985 events, plus historical events with more than 1 MDP) (Fig. 3b) in the same area have been illustrated. A high number of MDPs

TABLE 1

Summary of the visited archived. TotMDPs: total of new MDPs; newMDPs: MDPs unknown referred to known seismic events on ASMI; newEvents: MDPs referred to unknown seismic events on ASMI; doc.typology: main typology of documentation where MDPs evidences were found; contemporary: logical, whether the documents are contemporary to the events; source: direct- the author is the observer of the seismic events, reported-the author reported information of seismic events from external sources. *In the counting of newMDPs where excluded MDPs referred to seismic events outside the Piemonte region.

\begin{tabular}{|c|c|c|c|c|c|c|c|c|}
\hline archive & city & tot MDPs & newMDPs & newEvents & doc. typology & contemporary & source & year range \\
\hline City Library Historical Archive & Carmagnola & 1 & 0 & 1 & adminstrative & $\mathrm{Y}$ & direct & 1525 \\
\hline $\begin{array}{l}\text { Historical Archive of the Italian } \\
\text { Meteorological Society }\end{array}$ & Moncalieri & 260 & $0 *$ & 260 & scientific buletin & $\mathrm{Y}$ & direct+reported & $1867-1895$ \\
\hline $\begin{array}{l}\text { Historical Archive of the } \\
\text { Museum of Natural History } \\
\text { "P. Craveri" }\end{array}$ & Bra & 5 & 2 & 3 & $\begin{array}{l}\text { Correspondance, } \\
\text { Scient. Pub. }\end{array}$ & $\mathrm{Y}$ & direct+reported & $1862-1884$ \\
\hline Diocesan Historical Archive & Asti & 17 & 0 & 17 & Diary & $\mathrm{Y}$ & direct+reported & $1777-1817$ \\
\hline \multirow[t]{2}{*}{ City Library Archive } & Alba & 22 & 4 & 18 & Periodic journal & $\mathrm{N}$ & reported & $1541-1784$ \\
\hline & TOTAL & 305 & 6 & 299 & & & & \\
\hline
\end{tabular}

TABLE 2

The seismic sequence of 1771 felt in Alba and nearby location. Io: estimated Intensity as in DBMI15 (F: felt; SF: slightly felt; HF: Highly felt).

\begin{tabular}{|c|c|c|c|c|c|c|c|}
\hline date & hour & locality & latitude & longitude & Io & archive & note \\
\hline \multirow[t]{3}{*}{$28 / 01 / 1771$} & \multirow[t]{3}{*}{ Before 12:00 } & Alba & $44^{\circ} 41^{\prime} 59^{\prime \prime}$ & $8^{\circ} 02^{\prime} 04^{\prime \prime}$ & \multirow[t]{3}{*}{$\mathrm{F}$} & \multirow[t]{3}{*}{ Alba } & \multirow[t]{3}{*}{ nd } \\
\hline & & Castiglione Falletto & $44^{\circ} 37^{\prime} 24^{\prime \prime}$ & $7^{\circ} 58^{\prime} 35^{\prime \prime}$ & & & \\
\hline & & Monforte & $44^{\circ} 35^{\prime} 00^{\prime \prime}$ & $7^{\circ} 58^{\prime} 14^{\prime \prime}$ & & & \\
\hline $\begin{array}{c}29 / 01 / 1771 \text { to } \\
27 / 02 / 1771\end{array}$ & nd & Alba & $44^{\circ} 41^{\prime} 59^{\prime \prime}$ & $8^{\circ} 02^{\prime} 04^{\prime \prime}$ & $\mathrm{F}$ & Alba & Numbers of minor events \\
\hline 28/02/1771 & $11: 30$ & Alba & $44^{\circ} 41^{\prime} 59^{\prime \prime}$ & $8^{\circ} 02^{\prime} 04^{\prime \prime}$ & $\mathrm{F}$ & Alba & nd \\
\hline $28 / 02 / 1771$ & $12: 30$ & Alba & $44^{\circ} 41^{\prime} 59^{\prime \prime}$ & $8^{\circ} 02^{\prime} 04^{\prime \prime}$ & $\mathrm{F}$ & Alba & nd \\
\hline $28 / 02 / 1771$ & $21: 45$ & Alba & $44^{\circ} 41^{\prime} 59^{\prime \prime}$ & $8^{\circ} 02^{\prime} 04^{\prime \prime}$ & $\mathrm{HF} \backslash 6$ & Alba & Falling furniture, little damage \\
\hline $28 / 02 / 1771$ & 0:00:00 & Alba & $44^{\circ} 41^{\prime} 59^{\prime \prime}$ & $8^{\circ} 02^{\prime} 04^{\prime \prime}$ & $\mathrm{HF}$ & Alba & Three strong quakes \\
\hline 28/02/1771 & $2: 30$ & Alba & $44^{\circ} 41^{\prime} 59^{\prime \prime}$ & $8^{\circ} 02^{\prime} 04^{\prime \prime}$ & SF & Alba & Continuous tremor \\
\hline $28 / 02 / 1771$ & 3,15 & Alba & $44^{\circ} 41^{\prime} 59^{\prime \prime}$ & $8^{\circ} 02^{\prime} 04^{\prime \prime}$ & SF & Alba & Explosion and tremor \\
\hline $29 / 02 / 1771$ & nd & Alba & $44^{\circ} 41^{\prime} 59^{\prime \prime}$ & $8^{\circ} 02^{\prime} 04^{\prime \prime}$ & $\mathrm{F}$ & Alba & Numbers of tremors \\
\hline
\end{tabular}


TABLE 3

The seismic event of 01/06/1878. Numeric $I_{0}$ are expressed in MSC scale and based on effect description found in the archive evidence.

\begin{tabular}{|c|c|c|c|c|c|c|c|}
\hline Data & hour & Locality & latitude & longitude & Io & Archive & Note \\
\hline $1 / 06 / 1878$ & $10: 45$ & Mondovì & $44^{\circ} 23^{\prime} 45^{\prime \prime}$ & $7^{\circ} 49^{\prime} 03^{\prime \prime}$ & F & Moncalieri & nd \\
\hline $1 / 06 / 1878$ & $10: 45$ & Monchiero & $44^{\circ} 34^{\prime} 13^{\prime \prime}$ & $7^{\circ} 55^{\prime} 12^{\prime \prime}$ & F & Moncalieri & nd \\
\hline $1 / 06 / 1878$ & $10: 45$ & Cairo montenotte & $44^{\circ} 23^{\prime} 52^{\prime \prime}$ & $8^{\circ} 16^{\prime} 39^{\prime \prime}$ & F & Moncalieri & nd \\
\hline $2 / 06 / 1878$ & $1: 30$ & Cairo montenotte & $44^{\circ} 23^{\prime} 52^{\prime \prime}$ & $8^{\circ} 16^{\prime} 39^{\prime \prime}$ & F & Moncalieri & nd \\
\hline $1 / 06 / 1878$ & $10: 45$ & Acqui terme & $44^{\circ} 40^{\prime} 31^{\prime \prime}$ & $8^{\circ} 28^{\prime} 09^{\prime \prime}$ & F & Moncalieri & nd \\
\hline
\end{tabular}

stand out in the cell containing Moncalieri. The cells in the area Bra-Alba also bring to light more MDPs (Fig. 3a). The areas containing more epicentres correspond to the
North-South orientated area south of Moncalieri (Fig. 3b). Thus, MDPs density matches the high concentration of epicentres. The average Magnitude recorded in that area
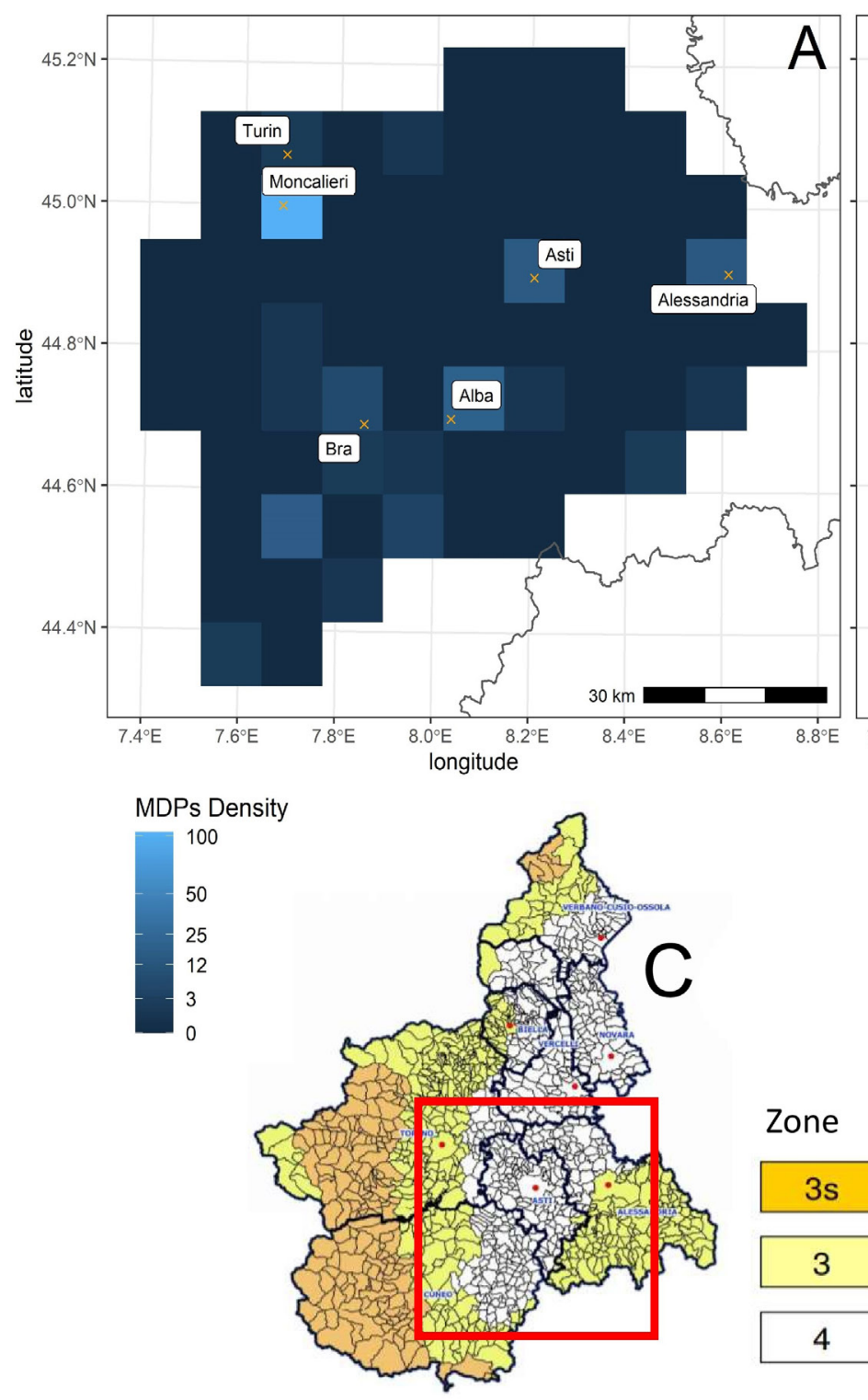

\section{Zone}

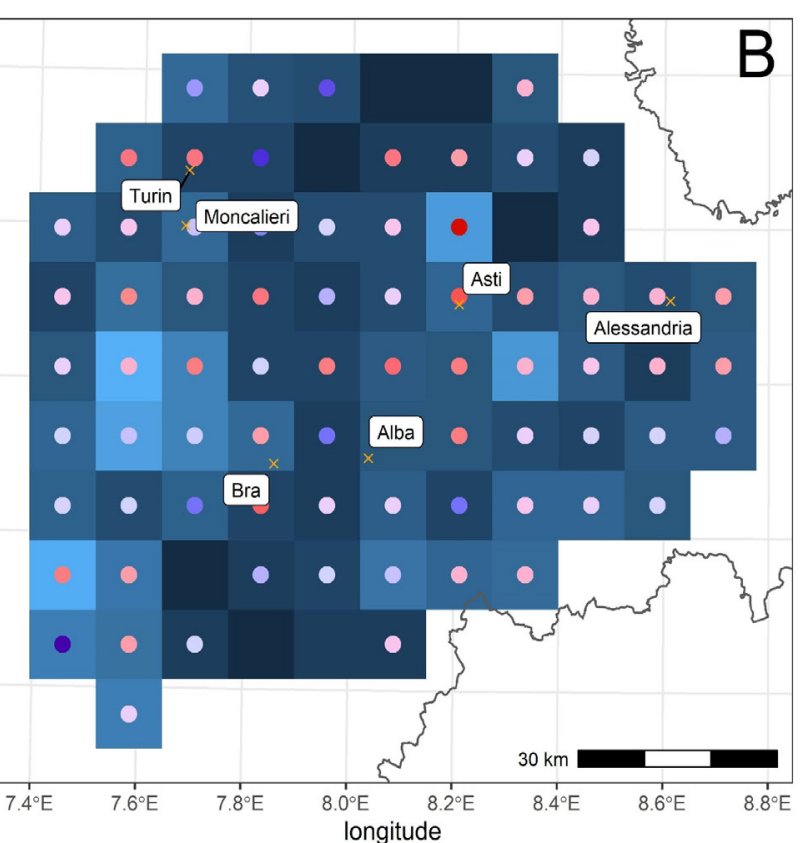

Average magnitude

Epicenter Density

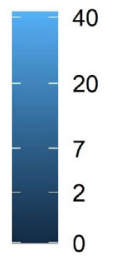

Fig. 3 - (a) density of MDPs as number of MDPs $/ 100 \mathrm{~km}^{2}$. (b) density of epicentre as number/100 $\mathrm{km}^{2}$; the colour of the points refers to the average magnitude of the seismic events. (c) Seismic zonation map of the Piedmont region (Regione Piemonte settore sismico,2020. D.G.R. 30 December 2019, nº 6-887, https://www.regione.piemonte.it/web/sites/default/files/media/documenti/2020-02/Classificazione\%20sismica\%20 Piemonte_2.pdf). In the red square the analysis area is shown. 
is $<3$ in all cells (Fig. 3b). This confirms the low intensity of the historical events recorded in Moncalieri and most of the MDPs classified as low intensity events (Tab. 2 and 3). The high density of epicentres near Asti (Fig. 3b) is confirmed by a concentration of MDPs in Asti, Alessandria, and Alba.

Consequently, the study area is confirmed to be strongly characterized by a microseismicity behaviour. In the last classification of the seismic zonation map (Fig. 3c), the area has been assigned to the $3^{\text {rd }}$ and $4^{\text {th }}$ seismic zones, the lowest in the Italian seismic categories (supposed to be the less struck by earthquakes in the past). Nevertheless, it should be stressed that the seismic sequence in January/ February 1771 (Tab. 2) gives some evidence of seismic events having caused considerable effect, including damages. The MDPs, located in Alba, are currently placed in $4^{\text {th }}$ seismic zone.

\section{EARTHQUAKE-INDUCED LANDSLIDES}

The 1985-2017 ARPA and INGV historical seismic databases, limited to the Piedmont region, include 20957 events, among which ten are between $M_{w} 4.0$ and $M_{w}$
5.3. SIFraP includes 5281 landslide points, 783 linear landslides, and 30696 areal landslides prior to 2017 (Fig. 4). Three of the examined landslide events can be associated with earthquakes, and all of them ascribable to rockfalls/topples. Two of them occurred in 1987 in Pont Canavese (TO): although they were recorded in September and October 1987, their extreme proximity in spatial terms (2.2 $\mathrm{km}$ and $1.6 \mathrm{~km}$ respectively) to the Frassinetto (TO) 03/07/1987 4.3 $\mathrm{M}_{\mathrm{w}}$ event presumes the earthquake may have acted as a predisposing factor (Fig. 5a). The third rockfall event was recorded on 18/04/2003 in Acqui Terme (AL): although the distance between the rockfall and the epicentre of the earthquake is huge (about $35 \mathrm{~km}$ ), it has been arguably associated with the Serravalle Scrivia (AL) $M_{w} 5.1$ earthquake on $11 / 04 / 2003$, the greatest of the last 35 years (Fig. $5 b)$

\section{DISCUSSION AND CONCLUSIONS}

The known seismic activity and local effects has been reviewed from different points of view. Seismic catalogues were checked, all the collected events were evaluated in spatial and temporal terms, and ten

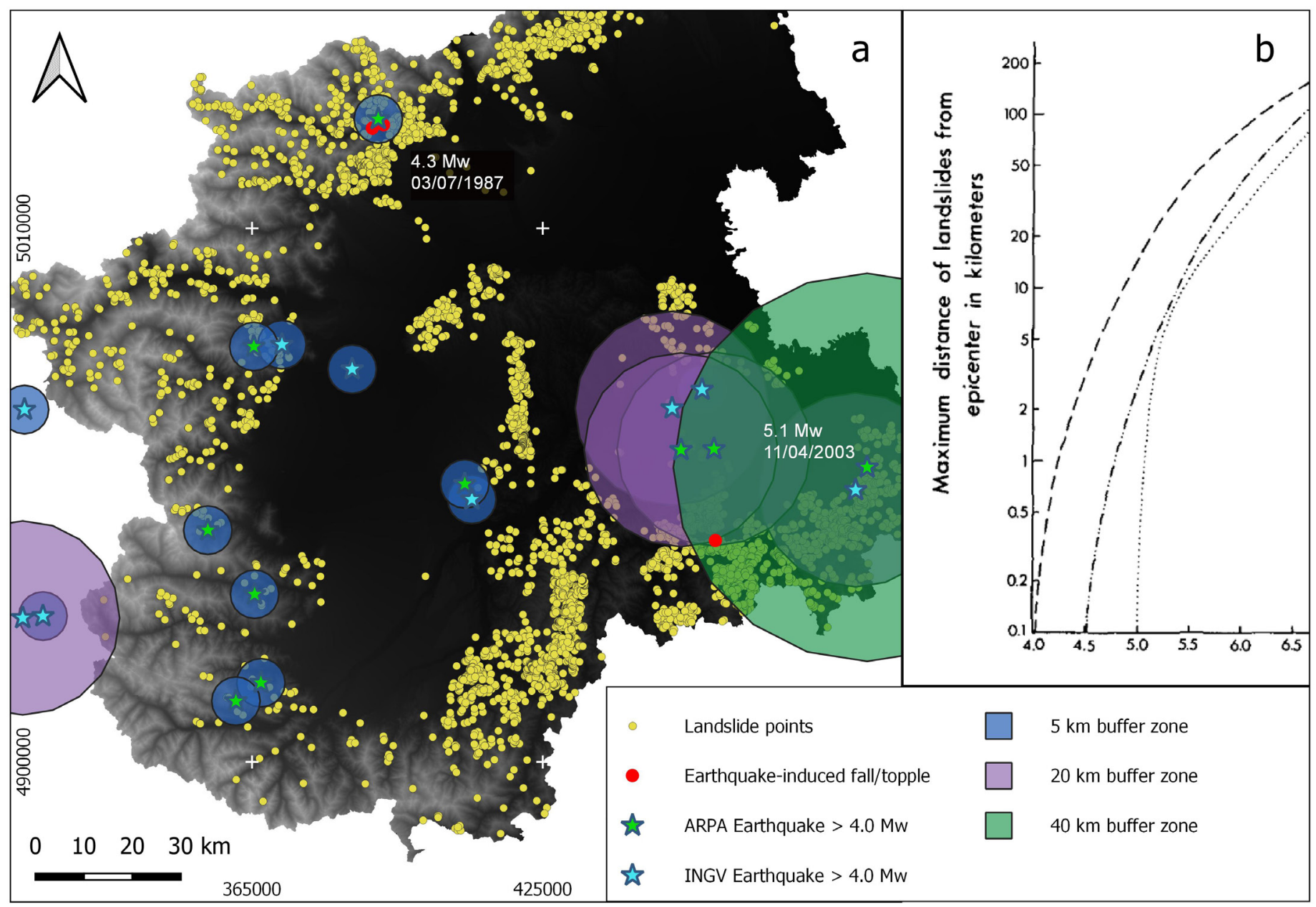

Fig. 4 - (a) The buffer zones overlaid on landslide points. The radius buffer area is $40 \mathrm{~km}$ for $\mathrm{M}_{\mathrm{w}}>5$ (green circle), $20 \mathrm{~km}$ for $\mathrm{M}_{\mathrm{w}}>4.5$ (violet circle), $5 \mathrm{~km}$ for $\mathrm{M}_{\mathrm{w}}>4$ (blue circle) as extrapolated by Keefer, 1984. (b) Comparison of upper bounds. The dashed line is the boundary for disrupted falls and slides, the dash-double-dot line is the boundary for coherent slides, and the dotted line is the boundary for lateral spreads and flows (from Keefer, 1984). 


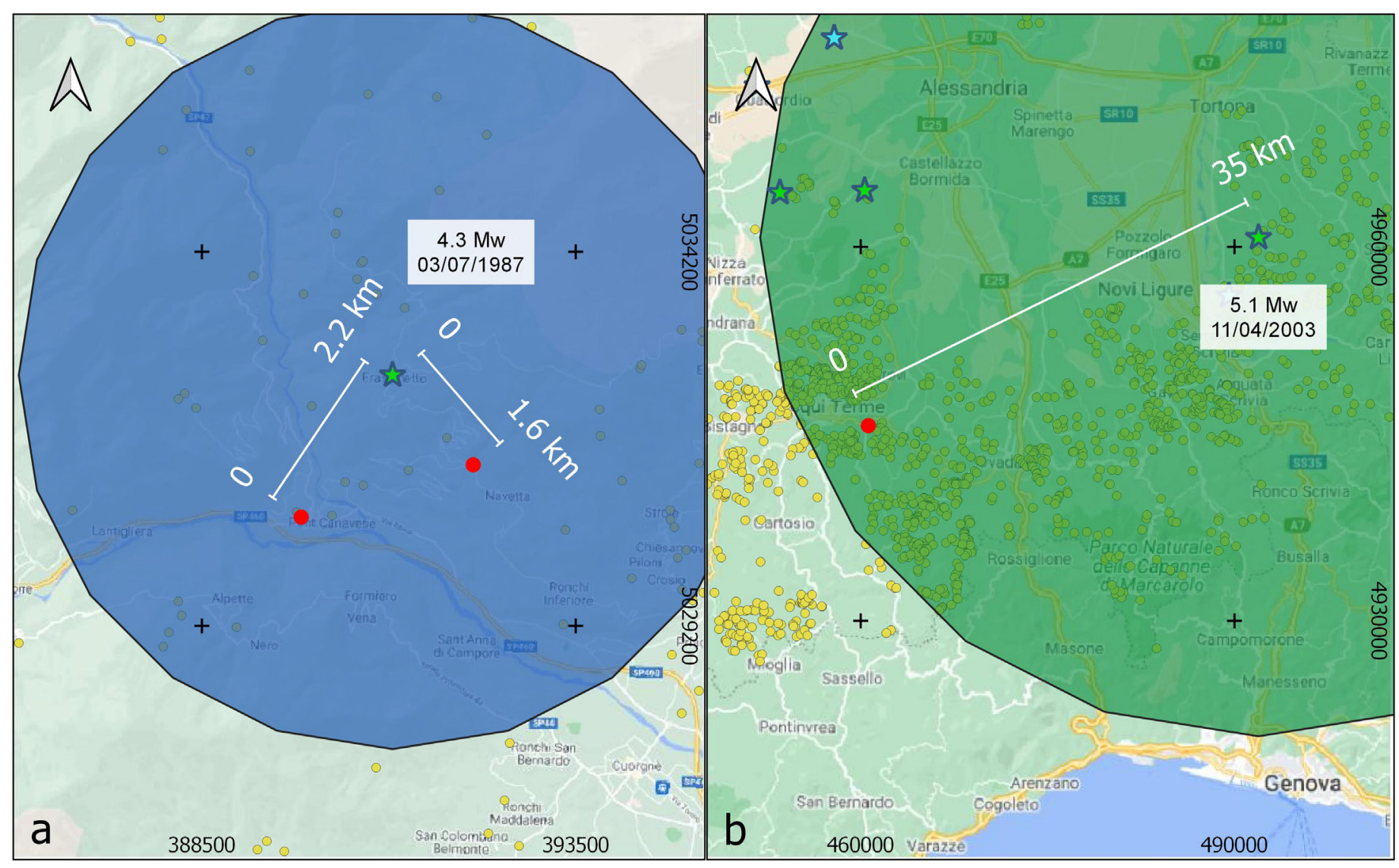

Fig. 5 - Focus on landslide events associated with earthquake: (a) the buffer zone around the Frassinetto (TO) 03/07/1987 earthquake, including two rockfalls/topples event in Pont Canavese; (b) the buffer zone around the Serravalle Scrivia (AL) 18/04/2003 earthquake, including a rockfall/ topple event near Acqui Terme (AL). Legend in Fig. 4.

archives were consulted to improve the historical seismic knowledge. New events for Alessandria, Asti, Cuneo, and Turin provinces were found, catalogued in a database, and collected in a georeferenced database. Through analyses of the regional instrumental seismicity, different clusters were defined based on hypocentre depths and locations. The present regional seismic classification map fits well to major earthquakes of the past. In known-inliterature districts the present-day seismicity is present in its greatest expression. In the opposite way, this map does not deal with the same handling the zones where new Macroseismic Data Points were found by the archive consultations. Even these zones, anyway, are characterised by a low-intensity, instrumental seismicity. Notable is the 1878 earthquake (with five MDPs found), but the most glaring example is certainly represented by the 1771 Alba seismic sequence, having reached an MSC intensity of 6 , with rumbles, structural damages, and furniture fall for two months. An indication that even this region, placed in $4^{\text {th }}$ seismic zone, could be locally damaged by short return time, low energy events. Most of the new seismic events found consist in a single MDP. As 1771 and 1878 events demonstrate, further historical investigations are needed in the study area to find other MDPs relative to the new seismic events; this would allow to estimate their epicentre location. The latest step could represent a significant contribution to further validate or reconsider the current seismic risk zonation map for the study area.
In conclusion, historical seismicity has been updated enabling a comparison with the instrumental seismicity of southern Piedmont. The density of the new MDPs is a close representation of the seismicity recorded from 1985 to present. The significative amount of MDPs recorded in Moncalieri might imply a site effect or simply an elevated sensitivity of an installed, new seismometer. A preliminary attempt to focus on the site effects of the region has been made comparing earthquake datasets with landslide datasets. Despite being found in a different geographic location, the three earthquake-induced landslide events confirm the possibility of earthquakes to act as triggering factors for landslides points. As suggested by literature in fact, the rockfalls/topples are the most susceptible in a regional context characterised by a relatively low seismicity. Geological analyses can facilitate an assessment of the earthquake-induced hazard, possibly with the inspection of other seismic parameters, unfortunately not available for this research, and regional differences in lithology. Further detailed geomorphological, structural field surveys are fundamental to assess potential site effects and can help the characterization of eventual morphological anomalies.

The earnest wish is that the work may improve the ASMI catalogue by adding the new important seismic sequence, especially since it occurred in a region today considered to be at very low seismic risk. In addition, it is hoped the research may encourage further investigation on seismogenic sources to better assess the seismic hazard topic. 


\section{ACKNOWLEDGEMENTS}

Many thanks must be expressed to Laurie Jayne Kurilla for the English revision, and to all the staff of the cited, visited archives for availability and helpfulness in searching documents. Thanks to Luigi Lombardo for the suggestions on the earthquake-induced landslide topic and to ARPA Piemonte researchers for providing the regional seismic and landslide database.

\section{REFERENCES}

ARPAPiemonte(2004)-SIFraP-SistemaInformativoFraneinPiemonte. http://webgis.arpa.piemonte.it/geoportalserver arpa/catalog/search resource/details.page?uuid=ARLPA_TO:07.04.02-D_2011-03-24-11:43

ARPA Piemonte (2011) - Sismicità in Piemonte - Sismicità strumentale e Sismicità recente. http://webgis.arpa.piemonte.it/geoportalserver arpa/catalog/search/resource/details.page?uuid=ARLPA TO\%3A07.05.10D 2011-10-24-11\%3A04\&title=Arpa \%20Piemonte \%20-\%20 Sismicit\%C3\%A0\%20in\%20Piemonte\%20-\%20Sismicit\%C3\%A0\%20 strumentale $\% 20 \mathrm{e} \% 20$ Sismicit $\% \mathrm{C} 3 \% \mathrm{~A} 0 \% 20$ recente

DISS Working Group (2018) - Database of Individual Seismogenic Sources (DISS), Version 3.2.1: A compilation of potential sources for earthquakes larger than M 5.5 in Italy and surrounding areas. http://diss.rm.ingv.it/diss/, Istituto Nazionale di Geofisica e Vulcanologia; https://doi.org/10.6092/INGV.IT-DISS3.2.1

Fioraso G. (2016) - La terra trema. Il terremoto del 1808 nel Pinerolese. LAReditore. $208 \mathrm{pp}$.

Forno M.G., De Luca D.A., Bonasera M., Bucci A., Gianotti F., Lasagna M., Lucchesi S., Pelizza S., Piana F. \& Taddia G. (2018) - Synthesis on the Turin subsoil stratigraphy and hydrogeology (NW Italy). Alpine and Mediterranean Quaternary, 31(2), 1-24.

Guidoboni E. \& Ebel J.E. (2009) - Earthquake and tsunami in the past. A guide to techniques in Historical seismology. Cambridge University Press. 590 pp.
Irace A., Clemente P., Piana F., De Luca D.A., Polino R., Violanti D., Mosca P., Trenkwalders S., Natalicchio M., Ossella L., Governa M. \& Petricig M. (2010) - Hydrostratigraphy of the late MessinianQuaternary basins in southern Piedmont (northwestern Italy). Mem. Descr. Carta Geol. d'It., 90, 133-152.

ISIDe Working Group. (2017) - Italian Seismological Instrumental and Parametric Database (ISIDe). Istituto Nazionale di Geofisica e Vulcanologia (INGV). https://doi.org/10.13127/ISIDE

Locati M., Camassi R., Rovida A., Ercolani E., Bernardini F., Castelli V., Caracciolo C.H., Tertulliani A., Rossi A, Azzaro R., D'Amico S. \& Antonucci A. (2021) - Database Macrosismico Italiano (DBMI15), versione 3.0. Istituto Nazionale di Geofisica e Vulcanologia (INGV). https://doi.org/10.13127/DBMI/DBMI15.3

Mosca P., Polino R., Rogledi S. \& Rossi M. (2009) - New data for the kinematic interpretation of the Alps-Apennines junction (Northwestern Italy). Int. J. Earth Sci., 99, 833-849.

Rodriguez C., Bommer J. \& Chandler R. (1999) - Earthquake-induced landslides: 1980-1997. Soil Dyn. Earthq. Eng., 18, 325-346.

Rovida A., Locati M., Antonucci A. \& Camassi R. (eds.). (2017) - Italian Archive of Historical Earthquake Data (ASMI). Istituto Nazionale di Geofisica e Vulcanologia (INGV). https://doi.org/10.13127/asmi

Rovida A., Locati M., Camassi R., Lolli B. \& Gasperini P. (2020). The Italian earthquake catalogue CPTI15. B. Earthq. Eng., 18(7), 2953-2984. https://doi.org/10.1007/s10518-020-00818-y

Rovida A., Locati M., Camassi R., Lolli B., Gasperini P. \& Antonucci A. (2021). Catalogo Parametrico dei Terremoti Italiani (CPTI15), versione 3.0. Istituto Nazionale di Geofisica e Vulcanologia (INGV). https://doi.org/10.13127/CPTI/CPTI15.3

Tanyas H. \& Lombardo L. (2019) - Variation in landslide-affected area under the control of ground motion and topography. Eng. Geol., $264,105331$.

Wasowski J., Keefer D.K. \& Lee C.-T. (2011) - Toward the next generation of research on earthquake-induced landslides: current issues and future challenges. Eng. Geol., 122, 1-8. 